\title{
The WRF model performance for the simulation of heavy precipitating events over Ahmedabad during August 2006
}

\author{
S K DeB ${ }^{1, *}$, T P SRivastava ${ }^{2}$ and C M Kishtawal ${ }^{1}$ \\ ${ }^{1}$ Atmospheric Sciences Division, Meteorology and Oceanography Group, Space Applications Centre, \\ ISRO, Ahmedabad 380 015, India. \\ 2 Indian Air Force, AFCNWP, Subroto Park, New Delhi 110 010, India. \\ *e-mail: sanjib_deb@rediffmail.com sanjib_deb@sac.isro.gov.in
}

The summer monsoon season of the year 2006 was highlighted by an unprecedented number of monsoon lows over the central and the western parts of India, particularly giving widespread rainfall over Gujarat and Rajasthan. Ahmedabad had received $540.2 \mathrm{~mm}$ of rainfall in the month of August 2006 against the climatological mean of $219.8 \mathrm{~mm}$. The two spells of very heavy rainfall of $108.4 \mathrm{~mm}$ and $97.7 \mathrm{~mm}$ were recorded on 8 and 12 August 2006 respectively. Due to meteorological complexities involved in replicating the rainfall occurrences over a region, the Weather Research and Forecast (WRF-ARW version) modeling system with two different cumulus schemes in a nested configuration is chosen for simulating these events. The spatial distributions of large-scale circulation and moisture fields have been simulated reasonably well in this model, though there are some spatial biases in the simulated rainfall pattern. The rainfall amount over Ahmedabad has been underestimated by both the cumulus parameterization schemes. The quantitative validation of the simulated rainfall is done by calculating the categorical skill scores like frequency bias, threat scores (TS) and equitable threat scores (ETS). In this case the KF scheme has outperformed the GD scheme for the low precipitation threshold.

\section{Introduction}

The seasonal weather cycles with a unique monsoon period of rains over India is mainly due to permanent and semi-permanent synoptic features, which produce variability in the rainfall distribution both spatially and temporally. Numerous rivers and irrigation canals are also adding to the diversity in land soil moisture, which indirectly influences the summer monsoon rainfall over India. Gujarat state is located in the extreme western part of India with Thar desert in the north-east, Rann of Kutch in the west and the mighty Arabian Sea which envelops the state towards the south and south-west. The bulk of the rainfall activity over this region occurs during the months of July and August under the influence of synoptic scale systems like the monsoon lows/depressions or the mid-tropospheric cyclonic circulations. Ahmedabad located at $23.04^{\circ} \mathrm{N} / 72.38^{\circ} \mathrm{E}$, receives an average of $803.4 \mathrm{~mm}$ annual rainfall of which $765.7 \mathrm{~mm}$ occurs during the monsoon period (http://www.worldweather.org/066/c00522.htm).

The onset of summer monsoon takes place around the second week of June and withdrawal starts by the second week of September. The monthly rainfall amounts are $108.7 \mathrm{~mm}$, $265.3 \mathrm{~mm}, 219.8 \mathrm{~mm}$ and $171.9 \mathrm{~mm}$ for the months of June, July, August and September, respectively (http://www.worldweather.org/066/c00522.htm). During recent years, the rainfall activity has apparently been on the increase over central Gujarat. The variation in the mosaic of land characteristics, vegetation and distribution of urban and rural developments results in complex mesoscale and microscale flows over the state of Gujarat. Typical

Keywords. Rainfall; TRMM; inner and outer domains. 


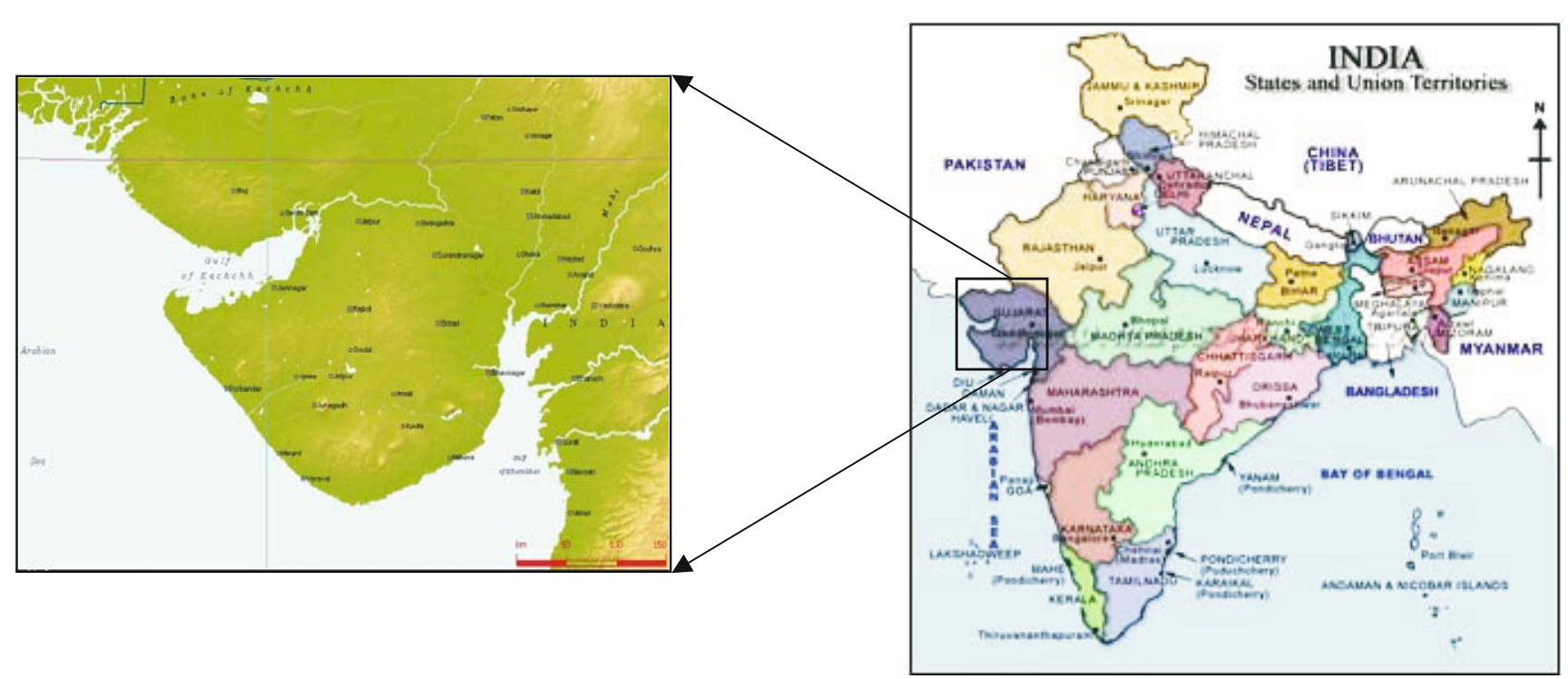

Figure 1. A map of India, including a map of Gujarat.

synoptic situations that affect the weather over Gujarat in conjunction with its unique geography and topography makes numerical weather prediction a multi-scale problem that involves synoptic scale features along with a variety of physics and parameterization schemes. It is due to these complexities that the use of an advanced mesoscale model in a nested configuration is a major requirement for simulating and forecasting the rainfall occurrences over this region.

\section{Numerical simulation of rainfall using WRF model: Background}

A real-time forecast over Taiwan was carried out by Ching et al (2005) by studying the typhoon Nida and a mesoscale convective system (MCS) during May 2004 using MM5/WRF mesoscale models. It has found that the timing of the MCS was slightly better captured by the WRF model than the MM5 model. However, the simulated rainfall amount in the WRF model was not large enough when compared with observations. The predicted rainfall amounts in the MM5 were more consistent with observations. The simulation of a high impact weather event over Israel was carried out with the WRF-Rapid Radiative Transfer Four Dimensional Data Assimilation (Dorita et al 2006) system. The WRF model has been used for simulation of thunderstorm at Machilipatnam over the east coast of India and a cyclonic circulation over Kerala (Vaidya 2007) and for simulation of the extreme rainfall event of 26 July 2005 over Mumbai (Vaidya and Kulkarni 2007; Deb et al 2008). In United States (US) this model is used for the prediction of warm season rainfall forecasts over the central US
(Gallus and Bresch 2006). Gallus and Bresch have carried out a comparison of impacts of the WRF dynamic core, physics package and initial conditions on warm season rainfall forecasts. A series of 15 simulations of weather events occurring in August 2002 were performed using the WRF model over a domain encompassing most of the central US to compare the sensitivity of the warm season rainfall forecasts with changes in the model physics, dynamics and initial conditions. Chang et al (2007) have carried out study of the impact of land surface parameterizations on the simulation of the July 26, 2005 heavy rain event over Mumbai, India. Sixteen numerical experiments were designed using two mesoscale models: the MM5 and the WRF, with three nested domains $(30,10$, and $3.33 \mathrm{~km}$ grid spacing), for various convective parameterizations, land surface schemes and land use/land cover conditions. Their studies reveal that the WRF model has better performance than the MM5 model in simulation of rainfall location and intensity.

\section{Heavy precipitation events over Ahmedabad: Two typical cases}

It is observed from the ground truth (actual rainfall recorded by the rain-gauge), given by the meteorological flights of the Indian Air Force, that during 7-8 August 2006, Ahmedabad $\left(23.04^{\circ} \mathrm{N}, 72.38^{\circ} \mathrm{E}\right)$, Gandhinagar $\left(23.12^{\circ} \mathrm{N}, 72.39^{\circ} \mathrm{E}\right)$ and Vadodara $\left(22.20^{\circ} \mathrm{N}, \quad 73.13^{\circ} \mathrm{E}\right)$ had received $108.8 \mathrm{~mm}$, $102.2 \mathrm{~mm}$ and $172.0 \mathrm{~mm}$ of rainfall (valid at $03 \mathrm{Z}$ ), respectively (figure 1). Another strong spell of rainfall was also observed during 11-13 August 2006 over the central part of Gujarat. During this period 


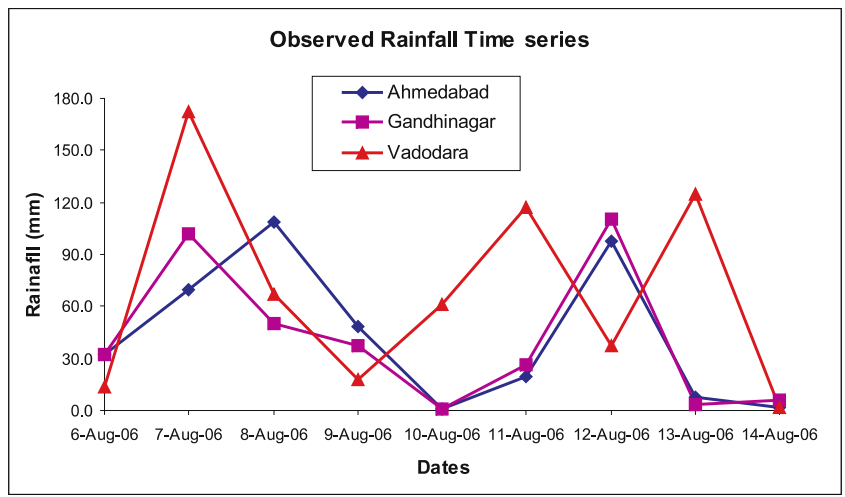

Figure 2. Time series of 24-hour accumulated observed rainfall $(\mathrm{mm})$ at Ahmedabad, Gandhinagar and Vadodara from the Indian Air Force ground-based observation.

observed rainfall of different central stations of Gujarat such as Vadodara recorded $117.1 \mathrm{~mm}$ and $124.9 \mathrm{~mm}$ on 11 August 2006 and 13 August 2006, Ahmedabad and Gandhinagar recorded $97.7 \mathrm{~mm}$ and $110.0 \mathrm{~mm}$ on 12 August 2006, Bhuj $\left(23.17^{\circ} \mathrm{N}\right.$, $\left.69.4^{\circ} \mathrm{E}\right)$, Jamnagar $\left(22.27^{\circ} \mathrm{N}, 70.05^{\circ} \mathrm{E}\right)$ and Naliya $\left(23.13^{\circ} \mathrm{N}, 68.53^{\circ} \mathrm{E}\right)$ recorded $86.8 \mathrm{~mm}, 220.2 \mathrm{~mm}$ and $172.4 \mathrm{~mm}$ on 13 August 2006 (courtesy Indian Air Force) respectively. These two cases of heavy rainfall events over Ahmedabad were selected for this study. The time series of observed rainfall $(\mathrm{mm})$ for Ahmedabad, Gandhinagar and Vadodara from 6th August 2006 to 14th August 2006 (figure 2) shows that the heavy rainfall spells occurred over most of the places between the 8 August 2006 and 13 August 2006. The second spell gave heavy rainfall over the central parts of Gujarat between 11 August 2006 and 12 August 2006 and during this period very heavy rainfall occurred over Vadodara $(117.1 \mathrm{~mm}$ and $124.9 \mathrm{~mm}$ on 11 August 2006 and 13 August 2006), Ahmedabad $(97.7 \mathrm{~mm}$ on 12 August 2006), Gandhinagar (110.0 mm on 12 August 2006).

During the active monsoon conditions in July/August the strong westerly or southwesterly flow over the Arabian Sea feeds in the formation of offshore trough over the sea off west coast. This triggers heavy rainfall activities in western India. The strengthening of this westerly or southwesterly takes place with either the Arabian Sea branch of the Indian monsoon being active or a depression or low-pressure system forms over the north Bay and moves to central India. The Global Data Assimilation System (GDAS) is an operational system and runs four times a day at the National Weather Service's National Center for Environmental Prediction (NCEP). The NCEP GDAS $1^{\circ} \times 1^{\circ}$ analysis was used to analyze the large-scale and synoptic-scale conditions over Gujarat during the above-mentioned cases. Both the lower and upper level large-scale flow patterns and moisture fields over the Indian region are analyzed with $850 \mathrm{hPa}$ and $300 \mathrm{hPa}$ winds and the vertical cross-section of relative humidity at $72.38^{\circ} \mathrm{E}$ valid at 00Z 8 August 2006 from the NCEP analyses shown in figure $3(\mathrm{a}-\mathrm{c})$. This shows the presence of strong cyclonic circulation in central India. It is also associated with a well-marked low-pressure system near the surface (figure not shown). It also shows the presence of strong westerly or northwesterly winds with a speed of $15-18 \mathrm{~m} / \mathrm{s}$ in the low level at $850 \mathrm{hPa}$ (figure 3a) over the west coast of India and westerly wind with a speed of $6-9 \mathrm{~m} / \mathrm{s}$ over south Gujarat. The low-level strong westerly or northwesterly winds become easterly or northeasterly at $300 \mathrm{hPa}$ (figure $3 \mathrm{~b}$ ) with a speed of $6 \mathrm{~m} / \mathrm{s}$ over Gujarat. The relative humidity was $90 \%$ over southern Gujarat and this strong moisture field is vertically extended up to $200 \mathrm{hPa}$ along the west coast of India, Gujarat and central India (figure 3c).

Tropical Rainfall Measuring Mission (TRMM) is a joint mission between NASA and the Japan Aerospace Exploration Agency (JAXA), to monitor tropical and subtropical precipitation and to estimate its associated latent heating. TRMM provides systematic visible, infrared and microwave measurements of rainfall in the tropics as key inputs to weather and climate research. TRMM rainfall measurements are also analyzed for the above two cases to see how they are matching with ground based observation of Indian Air Force. The 24-hour accumulated rainfall (Day 1) valid at $03 Z$ of 08 August 2006 (figure 4a) from TRMM shows widespread rainfall along the west coast of India, Vidharbha, Marathwada, Maharashtra, Gujarat, south Rajasthan and adjoining Madhya Pradesh. More than $64 \mathrm{~mm}$ of rainfall was recorded over north Maharashtra, Marathwada, Maharashtra, Gujarat and south Rajasthan. Particularly more than $64 \mathrm{~mm}$ rainfall was recorded in the southeastern districts of Ahmedabad on that day. On the next day (figure 4b), the rainfall over southwest Rajasthan and the adjoining north Gujarat had shown a gradual shift in the northwest as well as northeast direction. The region of rainfall more than $64 \mathrm{~mm}$ remained over north Maharashtra and adjoining Arabian Sea but its aerial extent had reduced. The regions of rainfall more than $128 \mathrm{~mm}$ over north Maharashtra had reduced considerably. Ahmedabad lay in the rainfall belt of $64 \mathrm{~mm}$. The heavy rainfall belt of more than $64 \mathrm{~mm}$ lay in the eastern sector of Ahmedabad previous day shifted northward. The rainfall in east Rajasthan had increased and regions have nearly $64 \mathrm{~mm}$ of rain on that day. The 24-hour accumulated rainfall valid at $03 Z$ of 12 August 2006 (figure 4c) from the TRMM shows widespread rainfall along the west coast of India, Gujarat and 
a) $00 \mathrm{Z} 8$ August NCEP $850 \mathrm{hPa}$

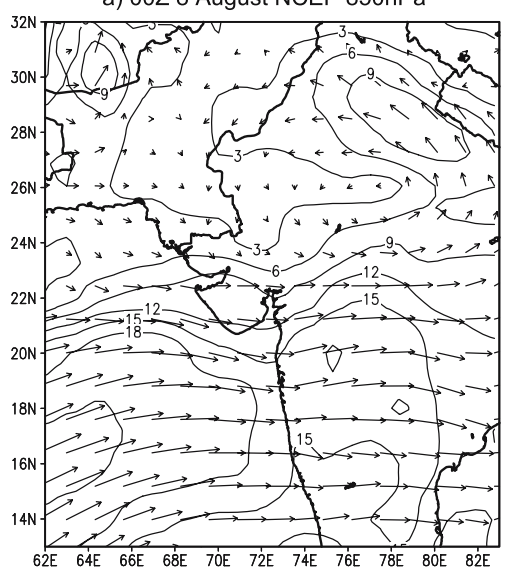

$\overrightarrow{25}$ b) $00 \mathrm{Z} 8$ August NCEP $300 \mathrm{hPa}$

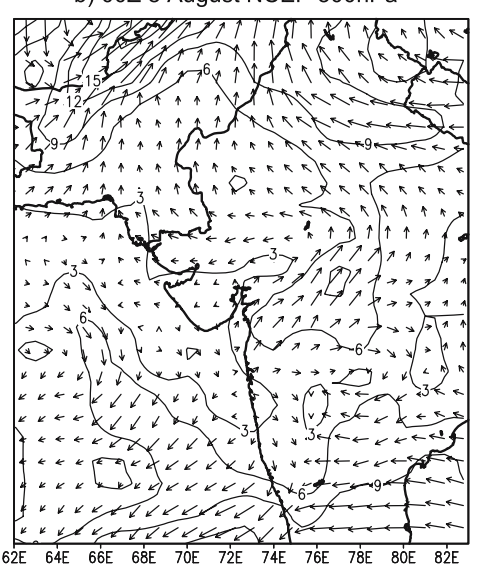

$\underset{25}{\longrightarrow}$

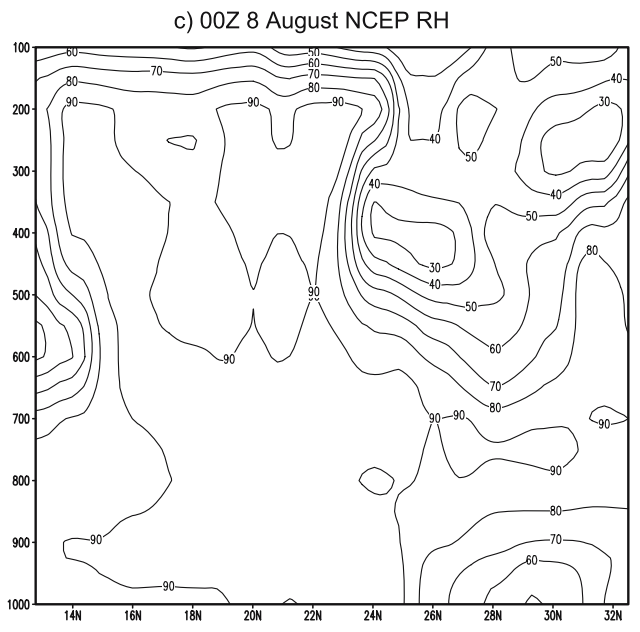

Figure 3. Winds (m/s) and relative humidity (\%) valid at 00Z 8 August 2006 from the NCEP analysis: (a) 850 hPa winds, (b) $300 \mathrm{hPa}$ winds and (c) vertical cross-section of relative humidity at $72.38^{\circ} \mathrm{E}$. (Contour levels 3 , 6, 9 , 12,15 , 18,21 for winds and 10 for relative humidity.)

a) $03 Z 8$ August TRMM Rain

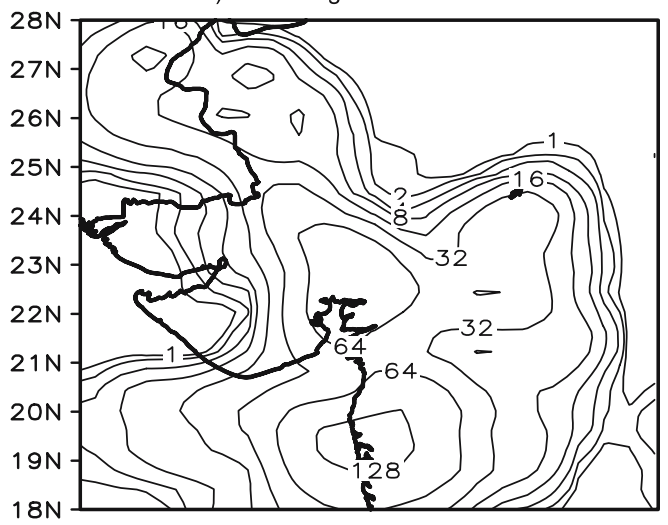

c) $03 Z 11$ August TRMM Rain

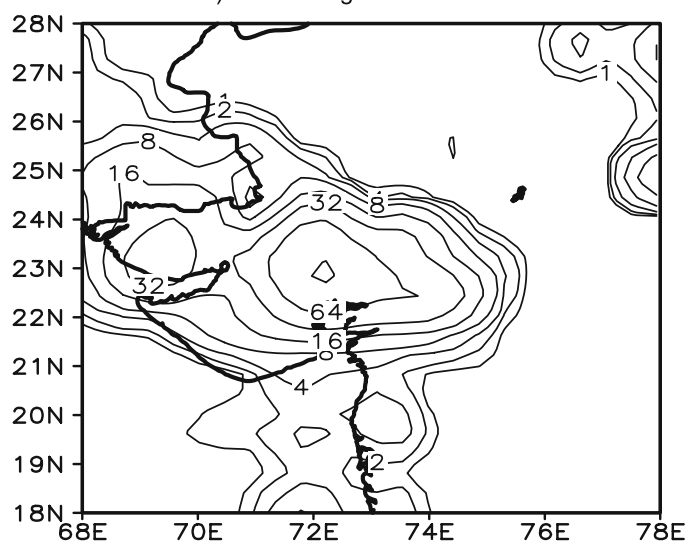

b) $03 Z 9$ August TRMM Rain

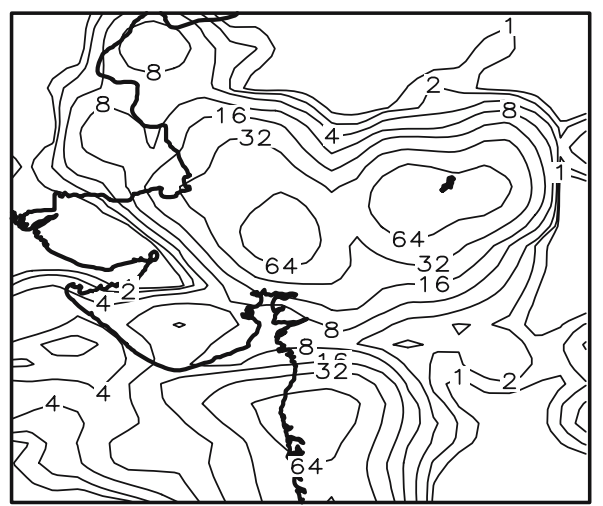

d) $03 Z 12$ August TRMM Rain

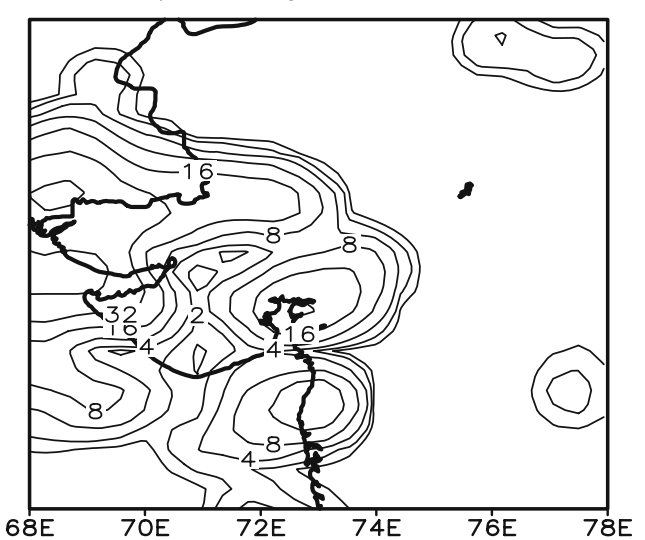

Figure 4. 24-hour accumulated rainfall (mm) from the TRMM valid at 03Z of: (a) 8 August 2006, (b) 9 August 2006, (c) 11 August 2006 and (d) 12 August 2006. (Contour levels 1, 2, 4, 8, 16, 32, 64 and 128.)

south Rajasthan. More than $64 \mathrm{~mm}$ of rainfall was recorded over northeast Gujarat and the adjoining south Rajasthan. More than $128 \mathrm{~mm}$ of rainfall was recorded over Ahmedabad, particularly in its southeastern districts. An east-west dipole like structure is clearly visible in the TRMM rainfall. On the next day (figure 4d), these heavy rainfall areas (of more than $64 \mathrm{~mm}$ ) rapidly shifted 
westward towards west Gujarat. The regions of rainfall more than $64 \mathrm{~mm}$ were not seen. Ahmedabad lay in the rainfall belt of $16 \mathrm{~mm}$. Though in both the cases the TRMM was able to capture the maximum rainfall amount of $128 \mathrm{~mm}$, however, the location is not very well captured. The ground based rainfall is a point measurement, while the resolution in TRMM rainfall is 0.25 degrees both along scan and pixel, this can be one of the reasons for their differences in magnitude. Though, the TRMM rainfall is a merged derived product of both IR and microwave measurements, however, sometimes TRMM underestimates the rainfall near the surface, which are due to warm clouds.

\section{The WRF model and experimental design}

The mesoscale model used in this study is the Weather Research and Forecasting (WRF-ARW version) Model version 2.0.1 developed primarily at National Center for Atmospheric Research (NCAR) with collaboration of different agencies (Skamarock et al 2005). Due to meteorological complexities involved in simulating and forecasting the heavy rainfall occurrences over a tropical region; use of the WRF modeling system in a nested configuration has been selected for the present study. In this study the performance of the WRF model for the simulation of these two excessive rainfall events specifically over Ahmedabad has been attempted using two cumulus parameterization schemes, the Kain-Fritsch (Kain and Fritsch 1990, 1993) and the Grell-Devenyi ensemble (Grell and Devenyi 2002) schemes. Though this is a very preliminary study related to this model, this limited number of experiments definitely gives some clues about the model performances over Gujarat region. The Grell-Devenyi ensemble (GD) cumulus parameterization scheme consists of an ensemble of cumulus scheme in which multiple schemes are run within each grid box and the results are averaged to give the feedback to the model. All cumulus schemes in the GD scheme are of mass-flux nature, differing in updraft and downdraft with entrainment and detrainment parameters, and precipitation efficiencies. The dynamic control closures are based on either convective available potential energy (CAPE), or low-level vertical velocity or moisture convergence. Those based on CAPE either balance the rate of change of CAPE or relax the CAPE to a climatological value and those based on moisture convergence balances the cloud rainfall to the integrated vertical advection of moisture. The modified version of the Kain-Fritsch (KF) scheme is based on Kain and Fritsch (1990, 1993), but has been modified based on testing within the Eta model. The dynamic control closure is based on the CAPE removal technique. As in the original KF scheme, it utilizes a simple cloud model with moist updrafts and downdrafts, including the effects of detrainment, entrainment, and relatively simple microphysics. The new features added in this modified version of the KF scheme are: a minimum entrainment rate is imposed to suppress widespread convection in marginally unstable, relatively dry environments, shallow (non-precipitating) convection is allowed for any updraft that does not reach minimum cloud depth for precipitating clouds; this minimum depth varies as a function of cloud-base temperature, the entrainment rate is allowed to vary as a function of low-level convergence. In case of downdraft the following changes are made: source layer is made as the entire 150-200 hPa deep layer just above cloud base, mass flux is specified as a fraction of updraft mass flux at cloud base, detrainment is specified to occur in updraft source layer and below. Generally in the tropical region the convection occurs because of large-scale low-level moisture convergence or because of thermodynamic instability, which in turn depends on CAPE. The scientific basis for choosing these two schemes for this study is that both the schemes have taken care of the above aspects. The other different dynamical and physical options used in this study are given in table 1.

The six-hourly NCEP GDAS analyses were used for the preparation of initial and boundary conditions. For the two case studies, data from 7 August 2006 (00 UTC) to 9 August 2006 (06 UTC) and from 11 August 2006 (00 UTC) to 12 August 2006 (06 UTC) were used. The model uses various terrestrial datasets for terrain, land-use, soil type, soil temperature, vegetation fraction, snow, monthly albedo, etc. from the WRF User's website http://www.mmm.ucar.edu/wrf/users/. The domain of interest is centered at $23.0^{\circ} \mathrm{N}, 72.0^{\circ} \mathrm{E}$, with horizontal resolution of $45 \mathrm{~km}$ and $15 \mathrm{~km}$ in the outer and inner domains on Mercator scale projection having $51 \times 51 \times 31$ and $79 \times 79 \times 31$ grid points in $x, y$ and vertical directions respectively. Four experiments carried out with the above domain configuration are summarized in table 2 .

\section{Statistical interpretation on the performance of the model}

Apart from the ground-based observation, the TRMM rainfall is used to verify the simulated rainfall. The NCEP GDAS analyses are used to verify the simulated large-scale circulations pattern, moisture and relative humidity fields. The precipitation fields are generally verified by the 
Table 1. A summary of characteristics of the WRF model.

\begin{tabular}{ll}
\hline Characteristic feature & \multicolumn{1}{c}{ WRF } \\
\hline Nesting option used & Nest: $15 \mathrm{~km}$ inner and $45 \mathrm{~km}$ outer \\
Vertical co-ordinate & $\begin{array}{l}\sigma_{p} \text { terrain-following mass vertical co-ordinate } \\
\text { (Laprise 1992) }\end{array}$ \\
Horizontal grid & Arakawa C-grid \\
Time integration scheme & Third-order Runga-Kutta scheme \\
Microphysics & Single-moment 6-class graupel (WSM6) \\
& microphysics scheme \\
Convection & Grell-Devenyi ensemble scheme (Grell and \\
& Devenyi 2002) and Kain-Fritsch (Kain and \\
& Fritsch 1990, 1993) \\
Radiation & Rapid radiative transfer model (RRTM), Mlawer \\
& et al (1997) for Longwave Dudhia (1989) for \\
shortwave & MRF (Medium Range Forecast) Scheme, (Hong \\
Planetary boundary layer (PBL) & and Pan 1996) \\
Land surface model & Noah-LSM (Chen and Dudhia 2001) \\
\hline
\end{tabular}

Table 2. Experimental design.

\begin{tabular}{llllc}
\hline & \multicolumn{1}{c}{ Exp 1 } & \multicolumn{1}{c}{ Exp 2 } & Exp 3 & Exp 4 \\
\hline Start-date & 7 August 2006 (00Z) & 7 August 2006 (00Z) & 11 August 2006 (00Z) & 11 August 2006 (00Z) \\
End-date & 9 August 2006 (06Z) & 9 August 2006 (06Z) & 13 August 2006 (06Z) & 13 August 2006 (06Z) \\
Cumulus & Modified & Grell-Devenyi & Modified & Grell-Devenyi \\
parameterization & Kain-Fritsch & ensemble & Kain-Fritsch & ensemble \\
Experiments name & KFD1C1 & GDD1C1 & KFD1C2 & GDD1C2 \\
& KFD2C1 & GDD2C1 & KFD2C2 & GDD2C2 \\
\hline
\end{tabular}

Note: $\mathrm{C} 1$ and $\mathrm{C} 2$ represent case 1 and case 2. D1 and D2 represent outer and inner domains.

categorical skill score method, where forecasts are varied against the occurrence or non-occurrence of specific categories of predicted rainfall (Gandin and Murphy 1992). The common methods of categorical verification of the precipitation fields are based on the calculation of frequency bias B, threat score (TS) and equitable threat score (ETS). The area frequency bias $\mathrm{B}$ is defined as $B=F / O$, where $F$ is the number of stations for which the model predicted rainfall amount exceeded a certain threshold and $O$ is the number of stations that recorded at least the selected threshold. The threat score (TS) and the equitable threat score (ETS) are defined as:

$$
T S=\frac{C F}{F+O-C F}
$$

and

$$
E T S=\frac{C F-R}{F+O-C F-R}
$$

where $R$ is a random forecast defined as the product of $F$ and $O$, divided by the total number of $N$ of verified stations: $R=F O / N$ and $C F$ is the number of points where the rainfall from model forecast is equal to the observed one (correct forecast). The ETS is equivalent to $T S$ with a correction to remove the frequency bias from the random hits. These statistical measures are used extensively for evaluation of model forecast precipitation (Mesinger 1996; Lagouvardos et al 2003; Mazarakis et al 2006). Since, the focus of the present study is the simulation of rainfall and hence apart from rainfall, the analysis of the simulated circulation features $(850 \mathrm{hPa}$ and $300 \mathrm{hPa}$ winds), and moisture fields are also discussed for case 1. However, only rainfall is analyzed for case 2 in the following section. The qualitative validation of the simulated circulation and moisture fields are done by calculating their differences with the corresponding NCEP GDAS analyses. The simulated rainfall patterns are compared by calculating their differences from the TRMM rainfall in both the cases. The quantitative analysis of the simulated rainfall is also carried out by calculating the frequency Bias, 
a) $00 Z 8$ August NCEP-KFD1C1 $850 \mathrm{hPa}$

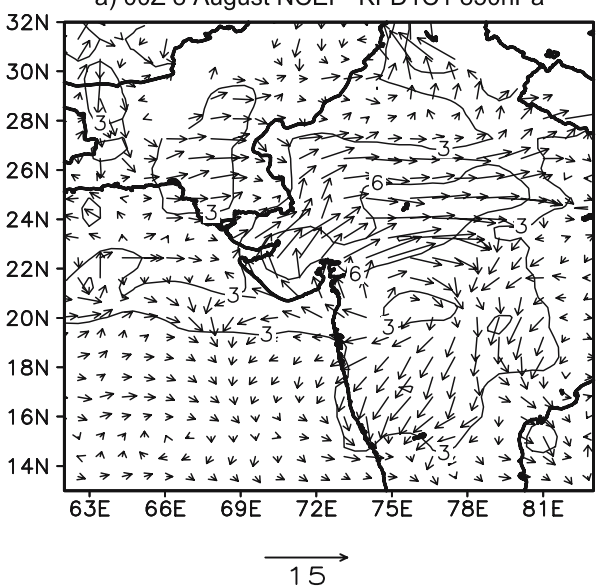

c) $00 Z 8$ August NCEP-GDD1C1 $850 \mathrm{hPa}$

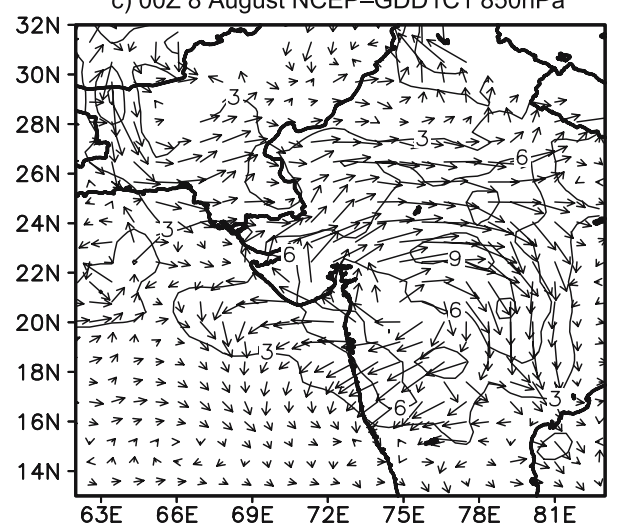

b) $00 Z 8$ August NCEP-KFD1C1 300hPa

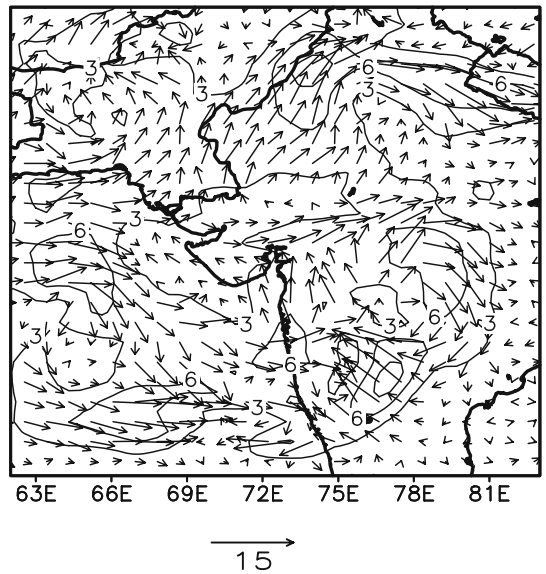

d) $00 \mathrm{Z} 8$ August NCEP-GDD1C1 $300 \mathrm{hPa}$

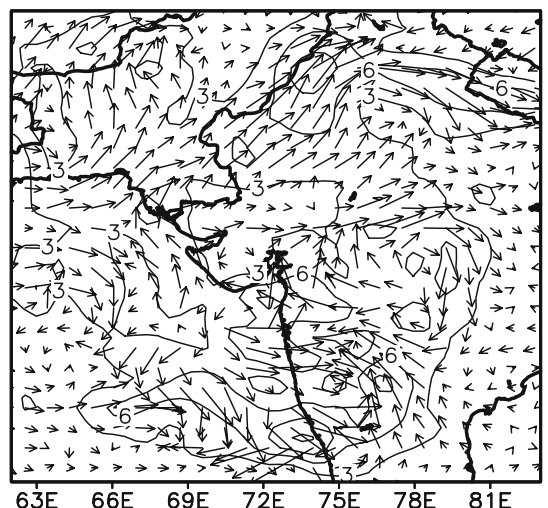

Figure 5. The difference of simulated winds $(\mathrm{m} / \mathrm{s})$ from the NCEP valid at 00Z 8 August 2006 from different experiments: (a) NCEP - KFD1C1 at $850 \mathrm{hPa}$, (b) NCEP - KFD1C1 at $300 \mathrm{hPa}$, (c) NCEP - GDD1C1 at $850 \mathrm{hPa}$ and (d) NCEP - GDD1C1 at $300 \mathrm{hPa}$. (Contour levels 3, 6, 9 and 12.)

TS and ETS for the first 24 hours of simulation in both the cases.

\subsection{Case 1 (7 August-9 August)}

The difference of simulated (KFD1C1 and GDD1C1) large-scale circulations (lower and upper levels) and vertical cross-section of relative humidity at $72.38^{\circ} \mathrm{E}$ from the NCEP analysis valid for $00 \mathrm{Z}$ of 8 August 2006 are shown in figures 5 and 6. Although both the experiments predicted reasonably strong Somali jet over the Arabian Sea, however it underestimated the strong westerly winds by $6 \mathrm{~m} / \mathrm{s}$ at $850 \mathrm{hPa}$ over entire Gujarat. The observed maximum speed was $9-12 \mathrm{~m} / \mathrm{s}$ over south Gujarat (figure 3a). The presence of strong cyclonic circulation over central India is also simulated very well in both the experiments. The lower level strong westerly winds become easterly at $300 \mathrm{hPa}$ (figure $5 \mathrm{~b}, \mathrm{~d}$ ) in the simulations. However, it has underestimated the easterly flow by $6 \mathrm{~m} / \mathrm{s}$ in both the experiments over Gujarat along $22^{\circ} \mathrm{N}$ and northerly wind of $6 \mathrm{~m} / \mathrm{s}$ present in the analysis along $72-75^{\circ} \mathrm{E}$ (figure $3 \mathrm{~b}$ ) is not seen in the simulations. Both the experiments have simulated the high values of relative humidity (figure $6 \mathrm{a}-\mathrm{b}$ ) up to $400 \mathrm{hPa}$ along the west coast of India, Gujarat and central India. In the analysis, the vertical extension of strong moisture fields was up to $200 \mathrm{hPa}$, however in both the simulations it was up to $400 \mathrm{hPa}$. Both the experiments have simulated strong moisture along $28-30^{\circ} \mathrm{N}$ at $300 \mathrm{hPa}$ over southern Rajasthan, which is not present in the analysis (figure 3c).

The difference of simulated 24-hour accumulated rainfall from the TRMM valid for $03 \mathrm{Z} 8$ August 2006 from KFD1C1, KFD2C1, GDD1C1 and GDD2C1 are shown in figure 7 . Though the pattern of rainfall from KFD1C1, i.e., the outer domain experiment (figure 7a) matches reasonably well with the TRMM rainfall, however it has underestimated the rainfall by about $30-60 \mathrm{~mm}$ along the Western Ghats, central Gujarat and southern tip of Rajasthan. A region of significant rainfall, more than $30 \mathrm{~mm}$, has been simulated over the southern and southwestern parts of Gujarat, which is not present in the TRMM rainfall. The corresponding inner domain experiment KFD2C1 of the KF scheme (figure 7b) has shown wide spatial distribution of rainfall as well 

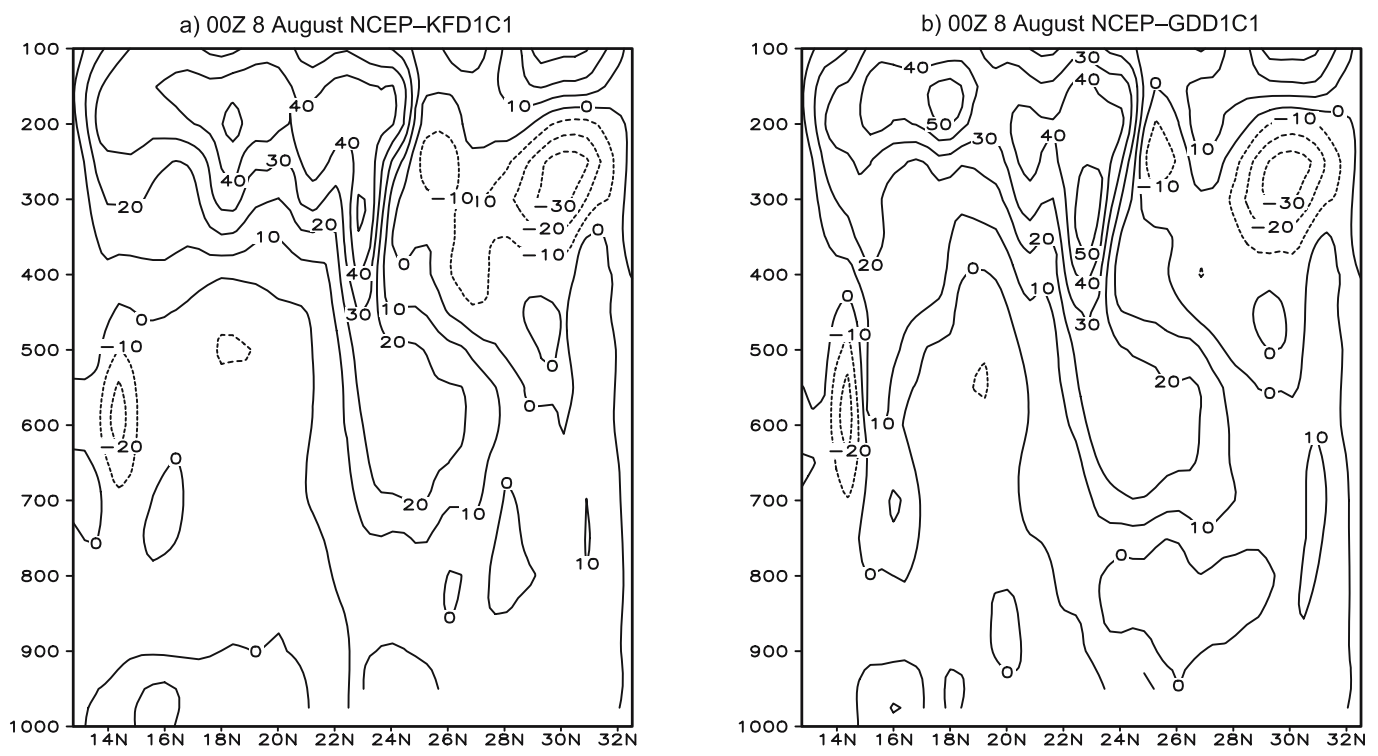

Figure 6. The difference of vertical cross-section of simulated relative humidity (\%) from the NCEP at $72.38^{\circ} \mathrm{E}$ valid at 00Z 8 August 2006: (a) NCEP - KFD1C1 and (b) NCEP - GDD1C1. (Contour levels 10.)

a) $03 Z 8$ August DIFF TR-KFD1C1

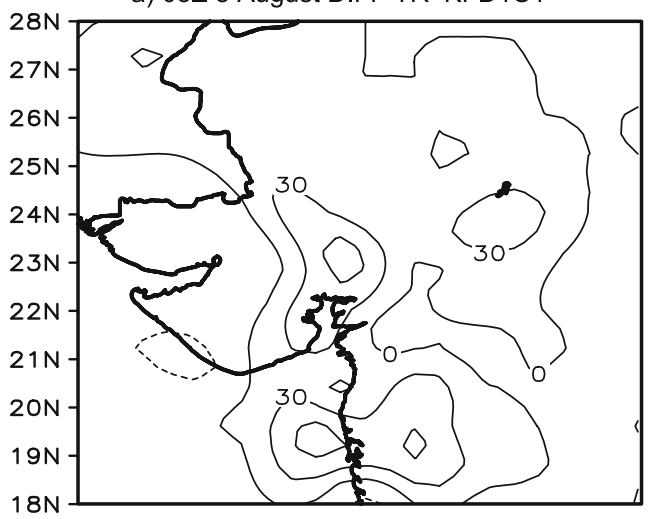

c) $03 Z 8$ August DIFF TR-GDD1C1

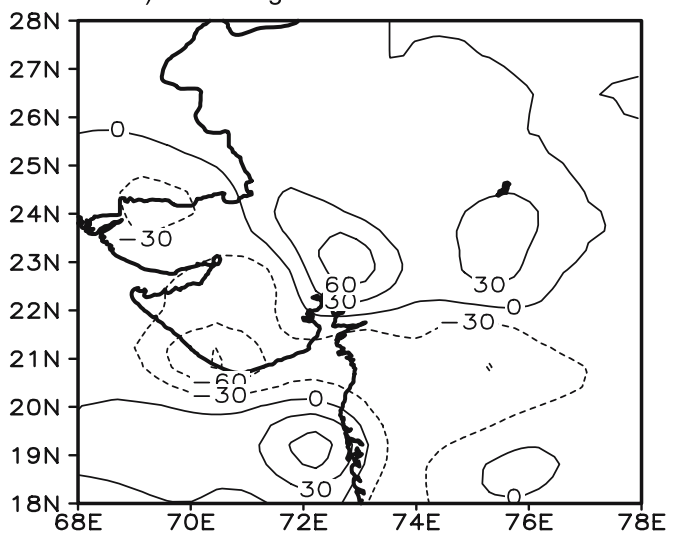

b) $03 Z 8$ August DIFF TR-KFD2C1

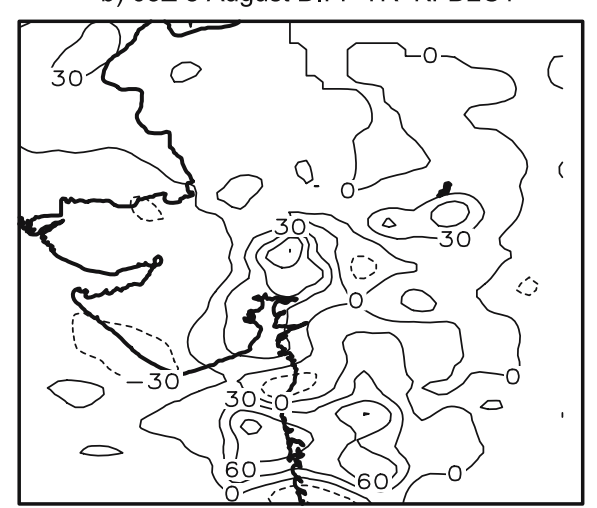

d) $03 Z 8$ August DIFF TR-GDD2C1

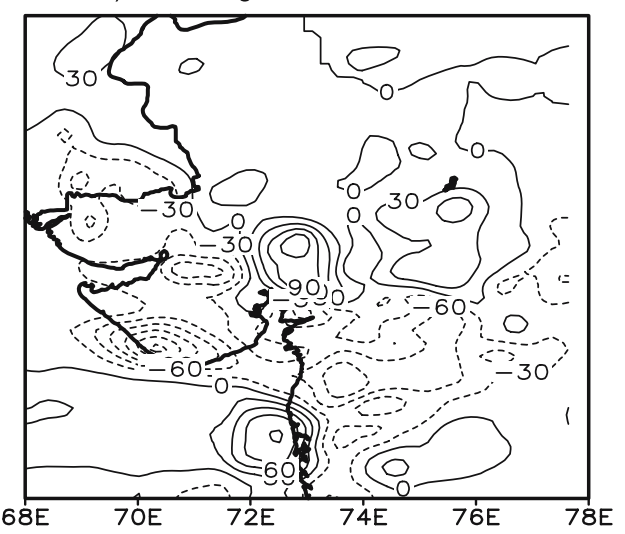

Figure 7. The difference of simulated rainfall $(\mathrm{mm})$ from the TRMM valid at $03 Z 8$ August 2006 from different experiments: (a) TR - KFD1C1, (b) TR - KFD2C1, (c) TR - GDD1C1 and (d) TR - GDD2C1. (Contour levels $30 \mathrm{~mm}$.)

as spatial coverage, however the magnitude of rainfall was underestimated by $30-60 \mathrm{~mm}$ as like in KFD1C1. The difference of simulated 24-hour cumulative rainfall from the TRMM in GDD1C1 valid for 03Z 8 August (figure 7c) shows that the magnitude of rainfall is overestimated by about 
a) $03 Z 9$ August DIFF TR-KFD1C1

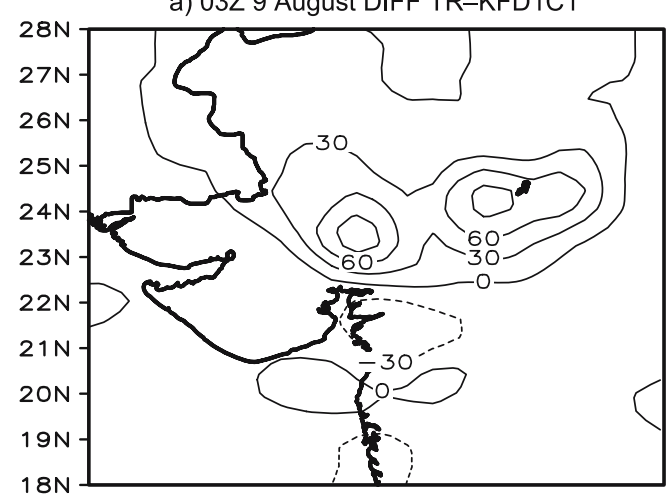

c) $03 Z 9$ August DIFF TR-GDD1C1

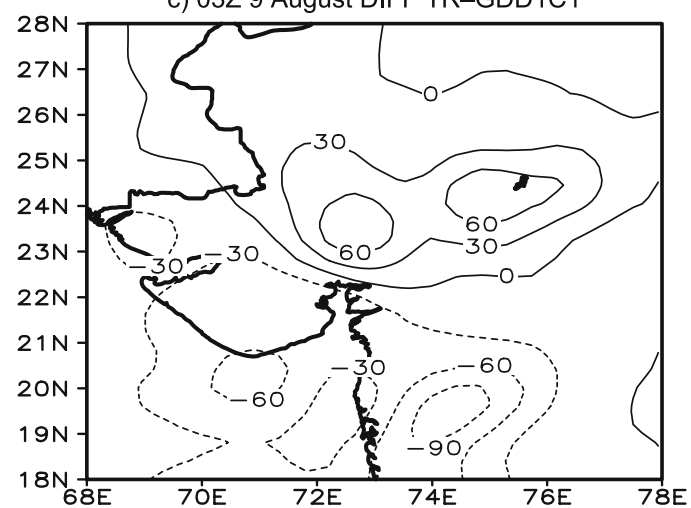

b) $03 Z 9$ August DIFF TR-KFD2C1

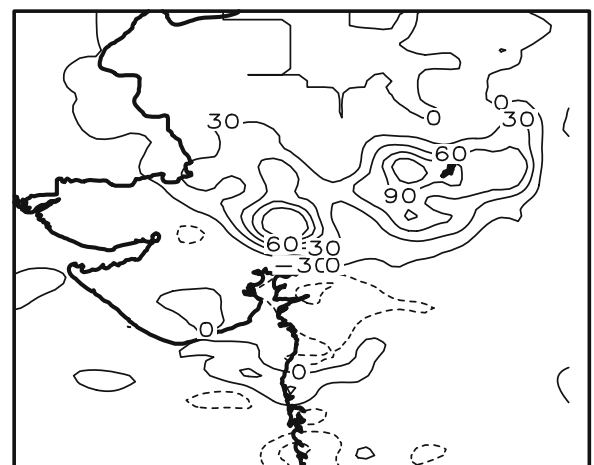

d) $03 Z 9$ August DIFF TR-GDD2C1

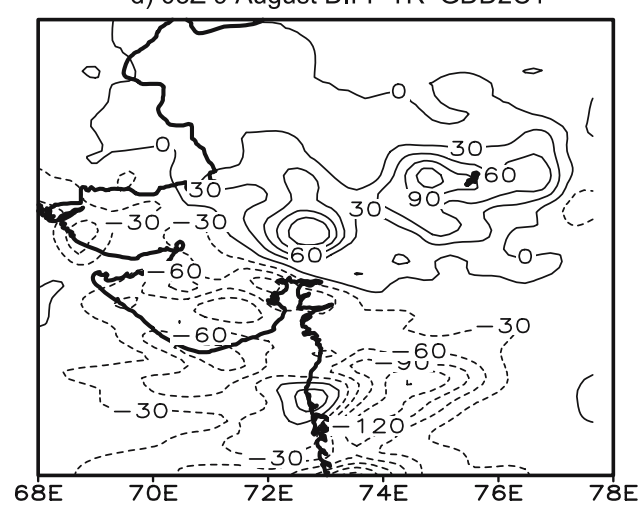

Figure 8. The difference of simulated rainfall $(\mathrm{mm})$ from the TRMM valid at 03Z 9 August 2006 from different experiments: (a) TR - KFD1C1, (b) TR - KFD2C1, (c) TR - GDD1C1 and d) TR - GDD2C1. (Contour levels $30 \mathrm{~mm}$.)

30-60 mm over north Maharashtra, Saurashtra and adjoining south Gujarat. However, it is underestimated over north Gujarat and Rajasthan by about $30-60 \mathrm{~mm}$. The model is able to simulate areas of rainfall more than $128 \mathrm{~mm}$ over north Maharashtra and the regions along the west coast of India. However, the location of these pockets has shifted eastward. Over Ahmedabad and adjoining regions, the model-simulated rainfall is $32 \mathrm{~mm}$, which is quite less as compared to the observed rainfall. Like in the KF scheme the model has also simulated an additional area of heavy rainfall of 30-60 mm over south Gujarat, which is not present in the TRMM observation. The corresponding inner domain (figure 7d) has shown the spatial distribution of rainfall to be the same as that of outer domain (figure 7c), with some more fine scale structures. Over Ahmedabad rainfall is still underestimated by about $60 \mathrm{~mm}$. Unrealistic heavy rains have also been simulated over south Gujarat in this domain too.

The difference of simulated 24-hour accumulated rainfall (Day 2) from TRMM valid for 03Z 9 August 2006 from KFD1C1, KFD2C1, GDD1C1 and GDD2C1 is shown in figure 8. With the KF scheme, although the model has been able to simulate the rainfall along the western coast of India (figure 8a), however, it has underestimated the rainfall by about $60 \mathrm{~mm}$ over northern Gujarat, east Rajasthan and west Madhya Pradesh, when compared with the TRMM rainfall. Over Ahmedabad and adjoining regions the model-simulated rainfall has reduced in intensity (in comparison to Day-1, $03 Z 8$ August 2006). In the inner domain experiment KFD2C1 (figure $8 \mathrm{~b}$ ), the spatial pattern is the same as that of outer domain with more small-scale features. Over Ahmedabad and adjoint areas, the model underestimated rainfall by about $60 \mathrm{~mm}$. The differences of simulated rainfall in GDD1C1 and GDD2C1 from the TRMM for both the inner and outer domain experiments valid at 03Z 9 August 2006 are shown in figure $8(\mathrm{c}-\mathrm{d})$. In the outer domain (figure $8 \mathrm{c}$ ) the model has overestimated the rainfall by $60-90 \mathrm{~mm}$ along the Western Ghat, Maharashtra and southern Gujarat, however the magnitude is underestimated by about $60 \mathrm{~mm}$ over northern Gujarat, west Madhya Pradesh and east Rajasthan. Over Gujarat the observed rainfall of more than $64 \mathrm{~mm}$ (or $128 \mathrm{~mm}$ ) is not present in the simulation. In the inner domain (figure 8d), the qualitative and quantitative assessment of the simulated rainfall is the same as that of outer domain with some finer details. The model has not been able to simulate 

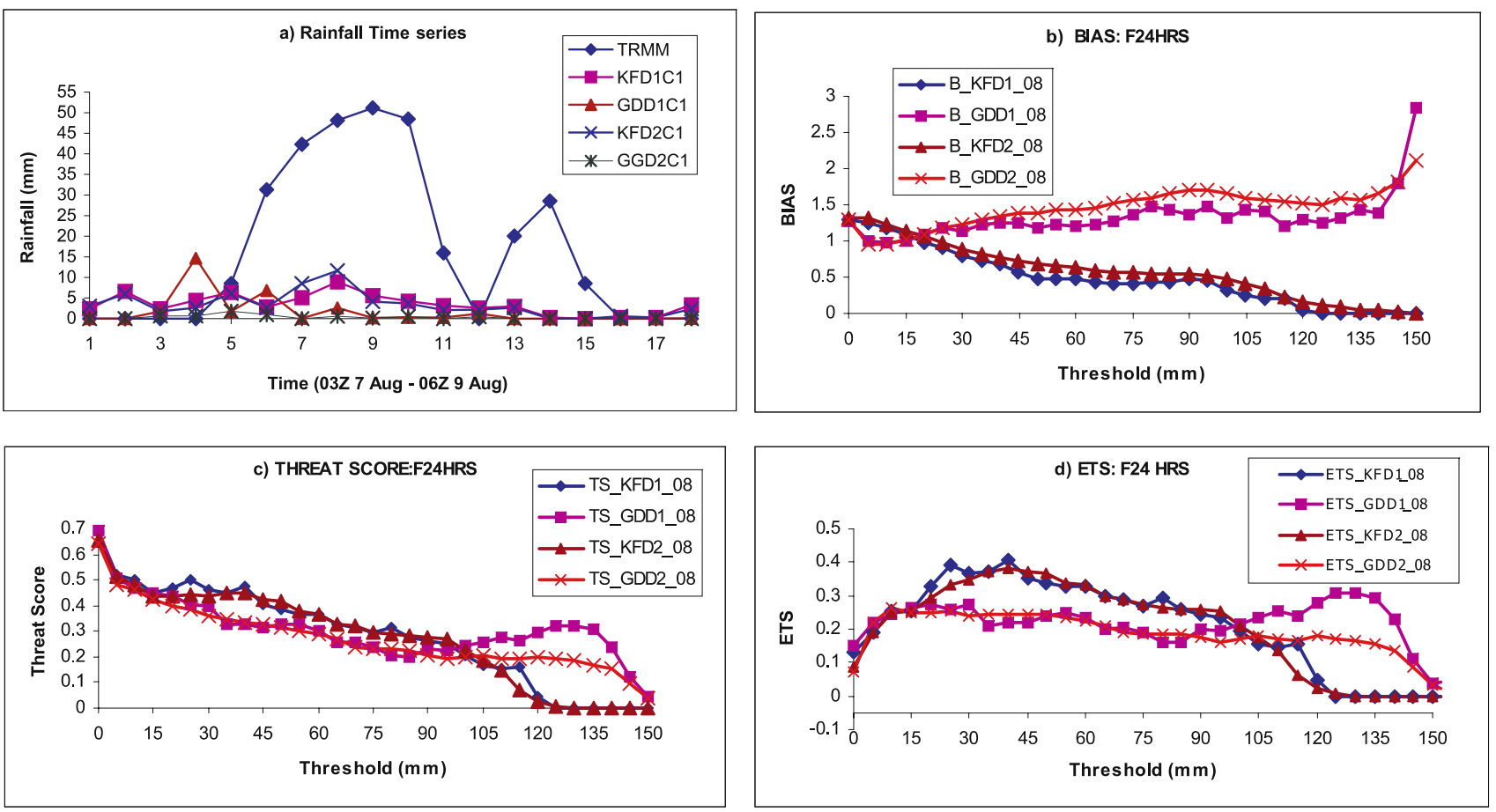

Figure 9. (a) Time series of 3-hourly cumulative rainfall from different experiments for case 1 and corresponding the TRMM observation over Ahmedabad. (b) Bias score for various precipitation threshold (mm) for first 24 hours forecasts in case 1 from different experiments. (c) Same as in (b) but for TS. (d) Same as in (b) but for ETS.

the heavy rainfall over the central/east Gujarat and adjoining regions of Rajasthan and west Madhya Pradesh.

The three-hourly cumulative rainfall time series over Ahmedabad from the different experiments for case 1 along with TRMM observation are shown in figure 9(a). The TRMM shows heavy rainfall of more than $35 \mathrm{~mm}$ over Ahmedabad from 18Z 7 August to 06Z 8 August 2006. All experiments have failed to simulate the heavy rainfall over Ahmedabad on 7-8 August 2006. Nonetheless, the simulation using the KF scheme is slightly better as compared to the corresponding simulation using the GD scheme. The frequency bias for the first 24-hour simulation for different rainfall threshold (in $\mathrm{mm}$ ) is shown in figure 9 (b). It is clearly visible from the figure that frequency bias scores in the KF scheme is greater than 1 (the perfect score) in the lowest precipitation threshold up to $15 \mathrm{~mm}$ rainfall threshold, thereafter it decreases gradually. In the GD scheme except for rainfall threshold $10 \mathrm{~mm}$ the bias score is always greater than 1. This shows that the GD scheme has a tendency to enlarge the forecast precipitation areas. The threat score values (figure 9c) for the KF scheme is slightly higher as compared to the GD scheme for a precipitation threshold up to $100 \mathrm{~mm}$, whereas it gradually increases in the GD scheme, unlike in the KF scheme. This shows that the KF scheme is better as compared to the GD scheme for precipitation up to $100 \mathrm{~mm}$. The equitable threat scores for the first 24-hour simulation for different thresholds are also shown in figure $9(\mathrm{~d})$. In the outer and inner domains the KF scheme has shown maximum score of 0.41 and 0.38 at $40 \mathrm{~mm}$ rainfall threshold, whereas the GD scheme has shown scores of 0.22 and 0.24 at this threshold value. The GD scheme has shown maximum scores of 0.31 for $135 \mathrm{~mm}$ rainfall threshold for the outer domain and the corresponding inner domain the maximum score is 0.26 for $10 \mathrm{~mm}$ rainfall threshold. This clearly indicates that for precipitation thresholds up to $90 \mathrm{~mm}$ the KF scheme performed much better as compared to the GD scheme, whereas for heavy precipitation $(>100 \mathrm{~mm})$ the GD scheme performs better than the KF scheme. Quantitatively as a whole, the simulation using the KF scheme is better as compared to the GD scheme for this specific case, though both the schemes have failed to simulate the exact location of intense rainfall over Ahmedabad.

\subsection{Case 2 (11 August-13 August)}

The difference of simulated 24-hour accumulated rainfall from TRMM valid at 03Z 12 August from $\mathrm{KFD} 1 \mathrm{C} 2$, KFD2C2, GDD1C2 and GDD2C2 is shown in figure 10. The rainfall from KFD1C2 i.e., the outer domain experiment (figure 10a) of the KF scheme underestimates the TRMM rainfall 

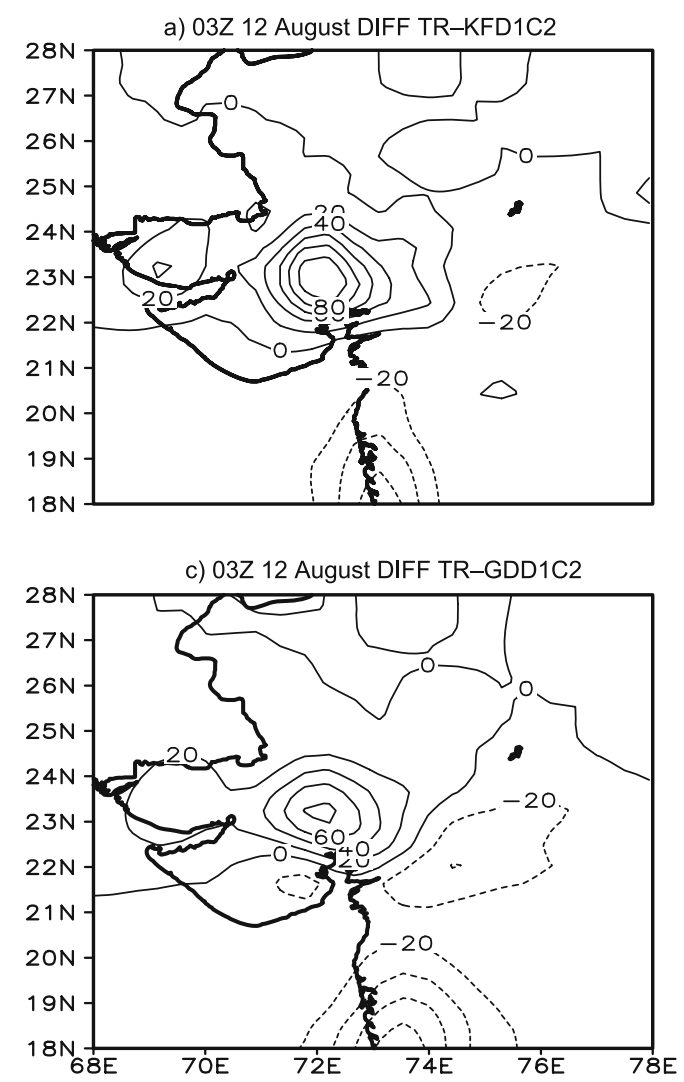

b) $03 Z 12$ August DIFF TR-KFD2C2

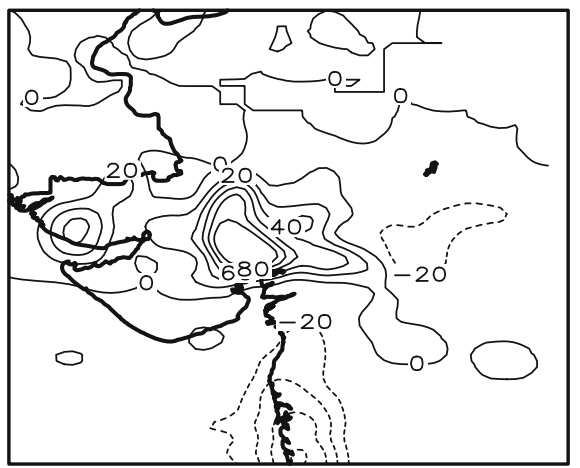

d) $03 Z 12$ August DIFF TR-GDD2C2

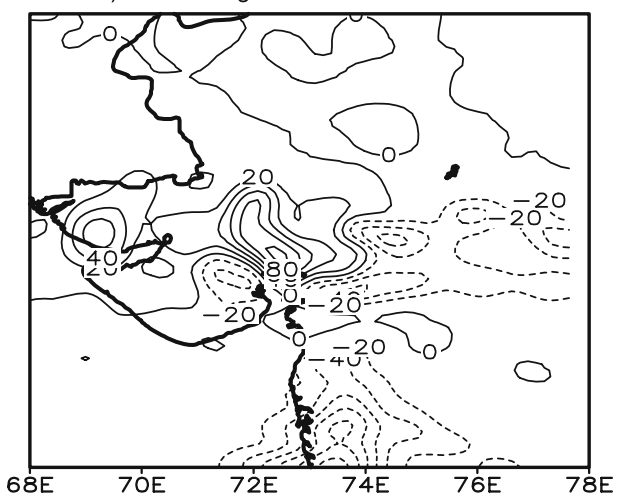

Figure 10. The difference of simulated rainfall ( $\mathrm{mm}$ ) from the TRMM valid at 03Z 12 August 2006 from different experiments: (a) TR - KFD1C2, (b) TR - KFD2C2, (c) TR - GDD1C2 and (d) TR - GDD2C2. (Contour levels $20 \mathrm{~mm}$.)

over most part of Gujarat and the areas with more than $128 \mathrm{~mm}$ have not been simulated in this experiment. In this region the rainfall is underestimated by about $80 \mathrm{~mm}$. However, along the western coast of India the model has overestimated the rainfall by about $40 \mathrm{~mm}$. The corresponding inner domain experiment $\mathrm{KFD} 2 \mathrm{C} 2$ of the $\mathrm{KF}$ scheme (figure 10b) has shown a similar spatial distribution of the rainfall as in the outer domain. The difference of simulated 24-hour cumulative rainfall from TRMM in GDD1C2 for 03Z 12 August (figure 10c) shows rainfall is underestimated by about $30 \mathrm{~mm}$ south of Gujarat and adjoining regions of north Maharashtra. In the northern Gujarat where actual rainfall was $128 \mathrm{~mm}$, the model has underestimated the rainfall by about $64 \mathrm{~mm}$. The corresponding inner domain (figure 10d) has also shown a similar spatial distribution of the rainfall over Gujarat with more small-scale features.

The difference of simulated 24-hour accumulated rainfall from the TRMM valid at 03Z 13 August from KFD1C2, KFD2C2, GDD1C2 and GDD2C2 is shown in figure 11. The inner domain of the KF scheme (figure 11a) shows a similar pattern as simulated by this scheme on the previous day though the spatial pattern in the outer domain has slightly improved on Day 2 as compared to Day 1 simulation, with two centres of maximum rainfall lying in the east-west direction as present in the observation. The areas of heavy rainfall over the extreme western parts of Gujarat have been simulated in both outer and inner domains on Day 2, however in both the cases the magnitude is underestimated by about $40 \mathrm{~mm}$. The corresponding difference of rainfall from the TRMM for GDD1C2 and GDD2C2 valid at 03Z 13 August is shown in figure $11(\mathrm{c}-\mathrm{d})$. In the outer domain (figure 11c) the model has simulated westward shift in the rainfall towards west Gujarat with an underestimation of $20 \mathrm{~mm}$. Over central Gujarat, the simulated rainfall matches reasonably well with the observation. In the inner domain (figure 11d), the movement of the heavy rainfall regions (more than $64 \mathrm{~mm}$ ) towards west Gujarat has been well simulated with an overestimation of rainfall amount by $40-60 \mathrm{~mm}$ along the west coast up to the Gulf of Cambay.

The three-hourly cumulative rainfall time series over Ahmedabad from different experiments for case 2 along with the TRMM observation are shown in figure 12(a). The TRMM shows heavy rainfall of more than $35 \mathrm{~mm}$ over Ahmedabad from 09Z 11 August to 03Z 12 August 2006. All the experiments have failed to simulate that spell over Ahmedabad on 11-12 August 2006. However, the 
a) $03 Z 13$ August DIFF TR-KFD1C2

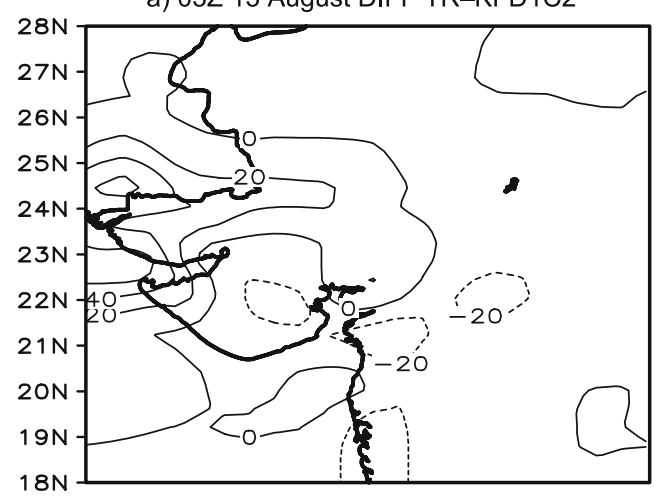

c) $03 Z 13$ August DIFF TR-GDD1C2

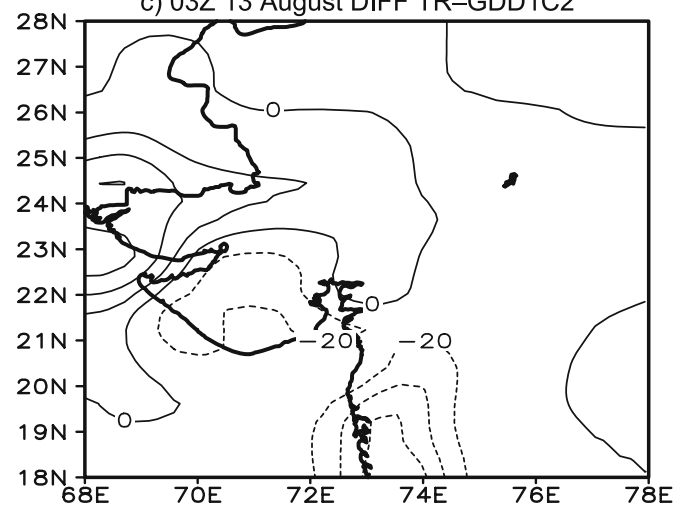

b) $03 Z 13$ August DIFF TR-KFD2C2

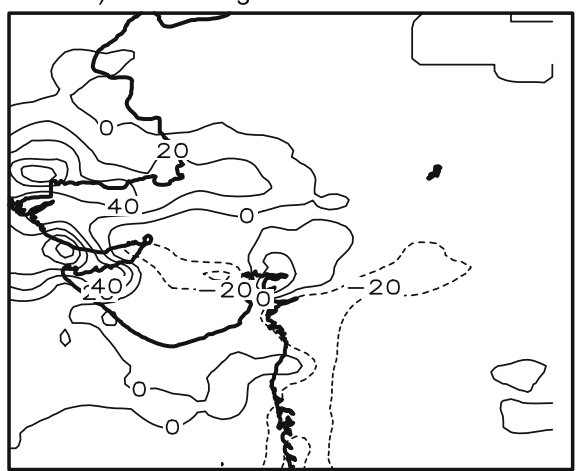

d) $03 Z 13$ August DIFF TR-GDD2C2

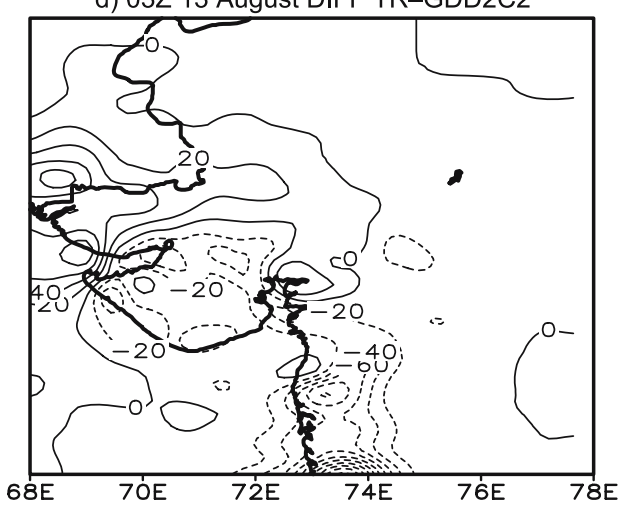

Figure 11. The difference of simulated rainfall $(\mathrm{mm})$ from the TRMM valid at $03 \mathrm{Z} 13$ August 2006 from different experiments: (a) TR - KFD1C2, (b) TR - KFD2C2, (c) TR - GDD1C2 and (d) TR - GDD2C. (Contour levels $20 \mathrm{~mm}$.)

experiment GDD1C2, i.e., the GD scheme at outer domain has shown some movement like TRMM with a time lag of 3 hours. Nonetheless the other simulations have failed to simulate the observed nature of heavy rainfall over Ahmedabad. The frequency bias for the first 24-hour simulation for different rainfall thresholds (in $\mathrm{mm}$ ) is shown in figure 12(b). It is clear from this figure that frequency bias score in the KF scheme is greater than 1 (the perfect score) in the lowest precipitation threshold up to $20 \mathrm{~mm}$ rainfall threshold, thereafter it decreases gradually. In the GD scheme frequency bias score is always greater than 1 except after $100 \mathrm{~mm}$ rainfall threshold in outer domain, whereas in the inner domain it increases. This shows that the GD scheme has a tendency to enlarge the forecast precipitation area. The threat score values (figure 12c) are better in the $\mathrm{KF}$ scheme as compared to the GD scheme for precipitation threshold up to $15 \mathrm{~mm}$. The equitable threat scores for the first 24-hour simulation for different thresholds are also shown in figure 12(d). The KF scheme both in outer and inner domains has shown maximum score of 0.24 at $5 \mathrm{~mm}$ rainfall threshold, whereas the GD scheme has shown scores of 0.15 and 0.14 at this threshold value. The GD scheme has shown maximum scores of 0.15 for $5 \mathrm{~mm}$ rainfall threshold for outer domain and for the corresponding inner domain the maximum score is 0.14 for $20 \mathrm{~mm}$ rainfall threshold. In this case it also observed that for lower precipitation thresholds performance of the KF scheme is better as compared to the GD scheme, whereas for higher thresholds the GD scheme is good. Quantitatively as a whole the simulation using the KF scheme is also better as compared to the GD scheme for this specific case, though both schemes have failed to simulate the exact location of intense rainfall over Ahmedabad.

\section{Conclusions}

A qualitative assessment of diagnostic investigation and the numerical simulations of two heavy rainfall events over Ahmedabad are attempted here with the WRF model using the GD ensemble and the KF cumulus parameterization schemes. The spatial pattern of simulated rainfall using both the cumulus schemes does not resemble well with the TRMM rainfall in terms of true location both in the inner and outer domains. Using the KF scheme the model has underestimated the rainfall over central Gujarat and west Madhya Pradesh by about $60 \mathrm{~mm}$ 

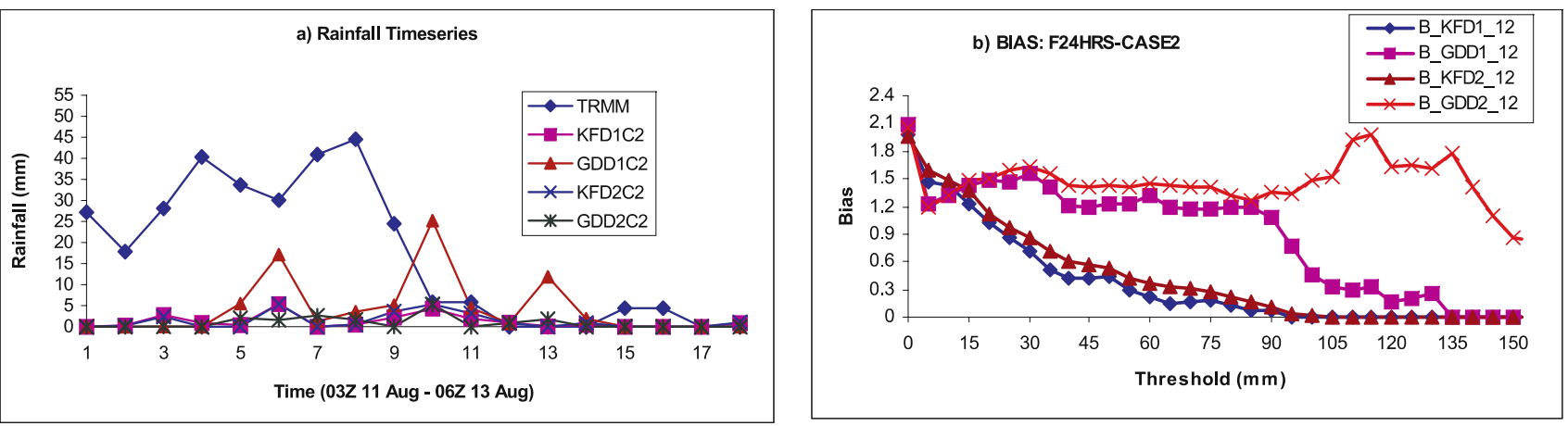

c) THREAT SCORE: F24 HRS-CASE2
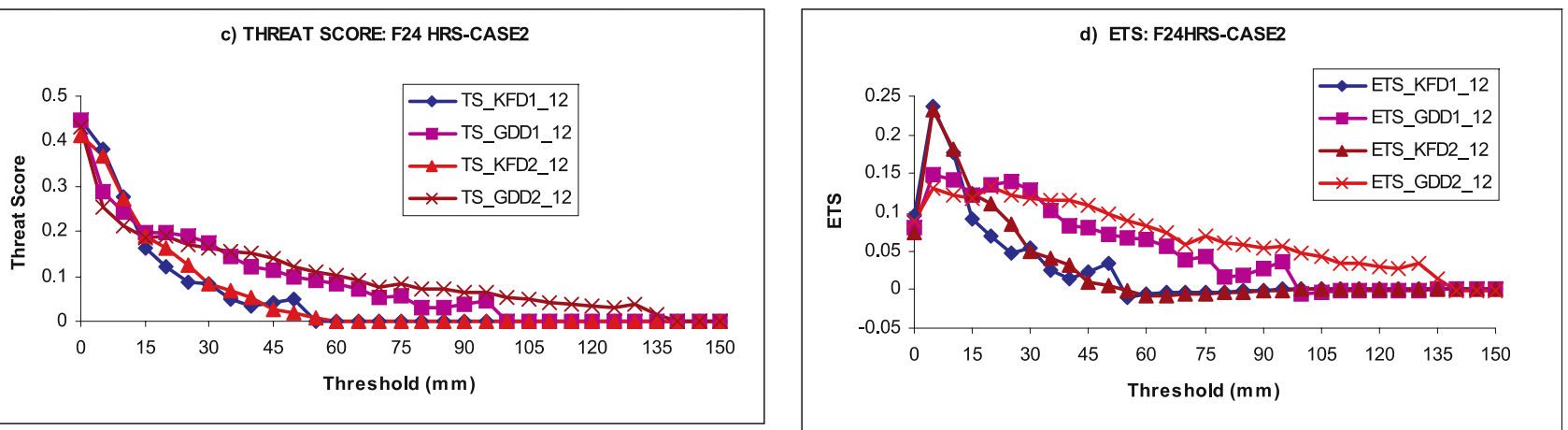

Figure 12. (a) Time series of 3-hourly cumulative rainfall from different experiments for case 2 and corresponding the TRMM observation over Ahmedabad. (b) Bias score for various precipitation threshold (mm) for first 24 hours forecasts in case 2 from different experiments. (c) Same as in (b) but for TS. (d) Same as in (b) but for ETS.

on both Day-1 and Day-2 in case 1, however for the Day-1 of case 2 the underestimation has increased up to $80 \mathrm{~mm}$. In the GD scheme the rainfall is overestimated by about $60 \mathrm{~mm}$ over Maharashtra and along the west coast of India, however it has underestimated the rainfall over central Gujarat by about $60 \mathrm{~mm}$ in both the cases as in the KF scheme. Both the schemes have a tendency to overestimate the rainfall over Maharashtra and west coast of India. This may be due to the presence of Western Ghats (a north-south mountain range in the western zone of India) in the west coast of India, where the model has a tendency to produce large rainfall because of orographic effect. The quantitative validation of the simulated rainfall is done by calculating the frequency bias, the threat score (TS) and the equitable threat scores (ETS) for various rainfall thresholds (figures 9 and 12). In case 1 , the $\mathrm{KF}$ scheme both outer and inner domains has shown maximum score of 0.41 and 0.38 at $40 \mathrm{~mm}$ rainfall threshold, whereas the GD scheme has shown scores of 0.22 and 0.24 at this threshold value. The GD scheme has shown maximum scores of 0.31 for $135 \mathrm{~mm}$ rainfall threshold for outer domain and the corresponding inner domain, the maximum score is 0.26 for $10 \mathrm{~mm}$ rainfall threshold. In case 2, the KF scheme both in outer and inner domains has shown maximum score of 0.24 at $5 \mathrm{~mm}$ rainfall threshold, whereas the
GD scheme has shown scores of 0.15 and 0.14 at this threshold value. The GD scheme has shown maximum scores of 0.15 for $5 \mathrm{~mm}$ rainfall threshold for outer domain and the corresponding inner domain the maximum score is 0.14 for $20 \mathrm{~mm}$ rainfall threshold. As a whole the simulation using the KF scheme is slightly better as compared to the GD scheme for both the cases, though both schemes have failed to simulate the true location of intense rainfall over Ahmedabad.

\section{Acknowledgements}

The authors thank the three anonymous reviewers for their critical and insightful comments and valuable suggestions, which were helpful in substantially improving the content and quality of presentation of this manuscript. The authors acknowledge the use of WRF model, which is available on internet by the NCAR and the WRF User Support Group for useful suggestions during the model installation. The authors also acknowledge the encouragement from the Director, SAC, Indian Space Research Organization (ISRO). One of the authors (TPS) also acknowledges the support from the Director, CSSTEAP and the Air Vice Marshal Ajit Tyagi VSM, Assistant Chief of Air Staff (Meteorology), at Directorate of Meteorology of 
the Indian Air Force for permission to participate in the SATMET course on Satellite Meteorology and Global Climate at SAC ISRO. The use of reanalyzed data from the NCEP, the TRMM rainfall from http://trmm.gsfc.nasa.gov, and the station rainfall data from Indian Air Force are thankfully acknowledged.

\section{References}

Chang H I, Kumar A, Niyogi D, Mohanty U C, Chen F and Dudhia J 2007 The Role of Land Surface Processes on the Mesoscale Simulation of the July 26, 2005 Heavy Rain Event over Mumbai, India; Global Planet. Change, submitted.

Chen F and Dudhia J 2001 Coupling an advanced landsurface/hydrology model with the Penn State/NCAR MM5 modeling system. Part-I: Model description and implementation; Mon. Wea. Rev. 129 569-585.

Ching F C, Jou B J D, Lin P-L and Hong J S 2005 A real-time MM5/WRF forecasting system in Taiwan, www.mmm.ucar.edu/MM5/workshops/ws04/PosterSession/Chien.Fang-Ching.pdf.

Deb S K, Kishtawal C M, Pal P K and Joshi P C 2008 Impact of TMI SST for the simulation of heavy rainfall episode over Mumbai on 26th July 2005; Mon. Wea. Rev. (doi: 10.1175/2008MWR2291.1), in press.

Dorita R-E, Lui L, Ge M, Warner T and Swaerdlin S 2006 Simulation of high impact weather event over Isreal with WRF-RTFDDA System - A Case Study, www.ucar.edu/wrf/users/workshops/WS2006/abstracts/ psession/P8_09_Rostkier_Edestien.pdf.

Dudhia J 1989 Numerical study of convection observed during the winter monsoon experiment using a meso-scale two-dimensional model; J. Atmos. Sci. 46 3077-3107.

Gallus Jr W A and Bresch J 2006 Comparison of impacts of WRF dynamic core, physics package, and initial conditions on warm season rainfall forecasts; Mon. Wea. Rev. $1342632-2641$.

Gandin L S and Murphy A H 1992 Equitable skill scores for categorical forecasts; Mon. Wea. Rev. 120 361-370.

Grell G A and Devenyi D 2002 A Generalised Approach to Parameterising Convection Combining Ensemble and
Data Assimilation Techniques; Geophys. Res. Lett. 29 38:1-38:4.

Hong S Y and Pan H L 1996 Nonlocal boundary layer vertical diffusion in a medium-range forecast model; Mon. Wea. Rev. 124 2322-2339.

Kain J S and Fritsch J M 1990 A One Dimensional Entraining/Detraining Plume Model and its Application in Convective Parameterisation; J. Atmos. Sci. 47 2784-2802.

Kain J S and Fritsch J M 1993 Convective parameterisation of mesoscale models: The Kain-Fritsch scheme; In: The Represenation of Cumulus Convection in Numerical Models (eds) Emanuel K A and Raymonds D J, Amer. Meteor. Soc., Boston, pp. 165-170.

Lagouvardos K, Kotroni V, Koussis A, Feidas C, Buzzi A and Malguzzi P 2003 The meteorological model BOLAM at the National Observatory of Athens: assessment of two-year operational use; J. Appl. Meteorol. 42 $1667-1678$

Laprise R 1992 The Eular equations of motion with hydrostatic pressure as independent variable; Mon. Wea. Rev. 120 197-207.

Mazarakis N, Kotroni V, Lagouvardos K and Music Nickovic S 2006 Impact of the assimilation of conventional data on the quantitative precipitation forecasts in the Eastern Mediterranean; Adv. Geo. Sci. 7 237-242.

Mesinger F 1996 Improvements in Quantitative Precipitation Forecasts with the ETA Regional Model at National Centers for Environmental Prediction: The 48-km Upgrade; Bull. Amer. Meteorol. Soc. 2637-2649.

Mlawer E J, Taubman S J, Brown P D, Iacono M J and Clough S A 1997 Radiative transfer for inhomogeneous atmosphere: RRTM, a validated correlated k-model for the longwave; J. Geophys. Res. 102(D14) 16,663-16,682.

Skamarock W C, Klemp J B, Dudhia J, Gill D O, Barker D M, Wang W and Powers J G 2005 A description of the Advanced Research WRF Version 2; NCAR Tech Note, NCAR/TN-468+STR, 88 pp. (Available from UCAR Communications, P. O. Box 3000, Boulder, CO 80307).

Vaidya S S and Kulkarni J R 2007 Simulation of heavy precipitation over Santacruz, Mumbai on 26 July 2005, using Mesoscale model; Meteorol. Atmos. Phys. 98 55-66.

Vaidya S S 2007 Simulation of weather systems over Indian region using mesoscale models; Meteorol. Atmos. Phys. 95(1-2) 15-26. 